\title{
Remembering Alma-Ata: challenges and innovations in primary health care in a middle-income city in Latin America
}

\author{
Adriano Massuda, ${ }^{1}$ César M. S. Titton, ${ }^{2}$ and Paulo Poli Neto ${ }^{3}$
}

Suggested citation Massuda A, Titton CMS, Neto PP. Remembering Alma-Ata: challenges and innovations in primary health care in a middle-income city in Latin America. Rev Panam Salud Publica. 2018;42:e157. https:// doi.org/10.26633/RPSP.2018.157

ABSTRACT The year 2018 is an opportune time to explore health system reforms and primary health care (PHC) in Brazil, given the anniversaries of the Alma-Ata Declaration (40 years) and of the Constitution of Brazil (30 years), the basis of the Unified Health System (SUS). In this context, health system analysis in the municipal setting is an important instrument for acknowledging achievements and innovations, as well as weaknesses and threats. Due to the principle of decentralization of SUS, municipalities have assumed a leadership role in health policy development and implementation. The cities also come first in expressing the failures of the health system and the consequences of austerity measures. Thus, analysis of health system transformations at the municipal level are fundamental to studying PHC achievements and gaps.

This report identifies the challenges and innovations of PHC implementation in Curitiba, beginning with a brief history of the city's health system development. The city was a pioneer in linking urban planning with health system design, improving access to health care, and obtaining better health outcomes over the past 30 years. This report covers those years, as well as the challenges and strategies implemented during the most recent political cycle (2013 - 2016). There are substantial lessons that can be garnered from the experience of this middle-income city in Latin America, lessons that may be useful as the region moves toward the Sustainable Development Goal of Universal Health Coverage by 2030.

Keywords Primary health care; health care reform; international acts; universal health coverage; Brazil; Latin America.

The $40^{\text {th }}$ anniversary of the Declaration of Alma-Ata (1) and the $30^{\text {th }}$ anniversary of the Constitution of Brazil (2), which created the country's Sistema Único de Saúde (Unified Health System; SUS), make 2018 an opportune time to explore health system reforms and the experiences of primary health care (PHC) initiatives.

\footnotetext{
Harvard T. H. Chan School of Public Health, Harvard University, Boston, Massachusetts, United States of America. Send correspondence to Adriano Massuda, a.massuda@gmail.com
}

Both provide substantive lessons in achievements and challenges for Latin America as the region moves towards the Strategic Sustainable Development Goal (SDG) of Universal Health Coverage (UHC) by 2030 (3).

The Declaration of Alma-Ata has been a guiding force for health policies based

\footnotetext{
Faculdade Evangélica do Paraná, Curitiba, Paraná, Brazil.

3 Departamento de Saúde Coletiva, Universidade Federal do Paraná, Curitiba, Paraná, Brazil.
}

on PHC globally; however, distinct meanings emerged according to regional and local contexts. In countries of Latin America, health system reforms were influenced by principles of equity, solidarity, and collective action to overcome social inequalities (4). In Brazil, the SUS was implemented in the early 1990s (5), and soon thereafter, the municipalities assumed a leading role for its expansion (6). PHC has been central to strengthening SUS, particularly through

cc) 
the Family Health Strategy (FHS) introduced by the National Policy for Primary Care (7). Major improvements have been achieved, including expanded coverage, better health outcomes, and reduced health inequalities $(8,9)$. However, significant disparities persist across geographic areas and among population groups $(10,11)$.

Furthermore, gaps in PHC functions remain present in Brazil, even where the SUS has had substantial progress (12). The recommendations from Alma-Ata still sound fresh. For many Brazilians, PHC services are not regularly the first level of contact; these services are usually available only where people live, not where they work; and PHC services are frequently unable to start a "continuous health care process" within themselves, less so if specialized services are involved. Such flaws in PHC are worsening rapidly due to the recent economic and political crises and the long-term austerity measures that have followed (13). The cities are where the health system failures are being exposed first (14). Thus, analysis of health system transformations at the municipal level are fundamental to understanding PHC achievements and gaps.

The objective of this report was to identify challenges and innovations in PHC implementation in Curitiba, the capital of the state of Paraná, in southern Brazil. Although this city may not be representative of the entire country, given its very high Municipal Human Development Index (15), it is a notable example of a well-established public health system in a large city in a middle-income country (16) of the Latin America. The historical context of Curitiba's municipal health system was reviewed, followed by an analysis of recent PHC gaps and the strategies implemented to address them in 2013 - 2016. Data used came from a review of the available literature; government data, including the municipal health plan for 2014 - 2017 (17); annual management reports for 2013 - 2016 (18); and selected health indicators from epidemiologic bulletins (19).

\section{HISTORIAL CONTEXT}

Curitiba has been a pioneer in urban planning, urban design innovations, public transportation, and environmental policy. Over time, these advances induced the growth of the municipal health system (Table 1). PHC services were first implemented in the late 1970s, prompted by the Alma-Ata recommendations to provide alternatives to the hospital for the poor population that had migrated from rural areas to the city. Municipal PHC units provided care based on vertical health programs for population groups and target diseases: child and maternal care, infectious diseases control, and later, some noncommunicable and chronic diseases, such as hypertension, diabetes, and mental health (20).

In the 1990s, with the implementation of the SUS, Curitiba became one of the first cities in the country to assume full responsibility for health system management. The city was divided into "health districts" to organize health planning and coordination (21). PHC coverage gradually increased. In 1992, the Family Medicine concept was introduced through cooperation with the Government of Canada. Since then, a dual model of PHC organization has been in place in the city. The "conventional model," based on internal medicine physicians, pediatricians, gynecologists, nursing professionals, and community health agents, who cover wider areas, predominated in the central PHC units; and the "family health" model, with each multiprofessional team (including a general practitioner) responsible for a list of territory-defined population, was implemented in new and peripheral PHC units. Curitiba was also a pioneer in the inclusion of dental teams in PHC (20).

From 2000 onwards, health care networks were established. The "Curitibana Mother" program was among the first to coordinate prenatal care between PHC units and maternity hospitals (22). Outof-hospital services were created following national policies and guidelines for emergency care (Serviço de Atendimento Móvel de Urgência and Unidade de Pronto Atendimento; UPA) and for mental health (Centro de Apoio Psicossocial), among others.

In parallel to the SUS, private health services grew, offering outpatient, hospital, and diagnostic services. From $2000-$ 2016, the population covered by private health insurance in Curitiba rose from $38 \%$ to $52 \%$.

Since the SUS implementation, there has a significant improvement in indicators: reduction of infant mortality (Figure 1); reduction of maternal mortality, from 53.6 / 100000 in 1996 to 23.9 in
2012, and to 8.6 in 2016; control of infectious diseases, such as tuberculosis; elimination of vertical transmission of HIV in 2013; and decrease in the hospitalization rate due to conditions that can be treated by outpatient services (23).

\section{CHALLENGES AT THE MUNICIPAL LEVEL}

Despite the advances, Curitiba faces challenges typical of any big city in Latin America. In 1980 - 2013, there was rapid population growth in Curitiba and its metropolitan area, from 1.5 million to 3.5 million people. This demographic transition increased the proportion of those middle-aged and elderly. The epidemiological shifts have resulted in a triple burden of diseases: increased violent deaths-Curitiba was ranked 42nd most violent city in the world in 2013 (24); expansion of chronic noncommunicable diseases, including cardiovascular, cancer, and mental health disorders; and persistence of infectious diseases, with high rates of leptospirosis mortality, late diagnosis of HIV/AIDS, and increasing incidence of congenital syphilis. Meanwhile, the health system expanded in services and management complexity, increasing its costs and requiring permanent innovation capacity, especially in PHC.

Popular demands regarding the municipal health system were one of the drivers for a government change in 2013, with the elected mayor emphasizing participative management, innovation, transparency, and humanization of public policies. The municipal planning for the 4-year period from 2014 - 2017 (17) defined the following five major challenges for the SUS in Curitiba.

\section{Lack of access to primary care}

Despite the city's 109 PHC units (in 2013), covering virtually the entire territory, access was a major problem. The predominant model of organization, based on vertical programs, provided medical appointments mostly for individuals who "fit" into the hypertension, diabetes, mental health, and maternal and child health services programs. This left few consultations, offered on a firstcome basis, for others. As a consequence, long queues formed in the early morning, before the units even opened for the day, and many people sought care in emergency clinics instead. 
TABLE 1. Highlights of the health system in the city of Curitiba, Paraná, Brazil, 1950 - 2016

\begin{tabular}{|c|c|c|c|c|c|c|c|}
\hline Context & 1950 & 1970 & 1980 & 1990 & 2000 & 2010 & 2016 \\
\hline International & & $\begin{array}{l}\text { Alma-Ata } \\
(1978)\end{array}$ & & & $\begin{array}{l}\text { Millennium Developme } \\
\text { Goals }\end{array}$ & & $\begin{array}{l}\text { Sustainable Development } \\
\text { Goals }\end{array}$ \\
\hline \multicolumn{8}{|l|}{ National } \\
\hline Political & Democracy & \multicolumn{2}{|c|}{$\begin{array}{l}\text { Military dictatorship } \\
\quad(1964-1985)\end{array}$} & \multicolumn{4}{|c|}{$\begin{array}{l}\text { Democracy } \\
\text { Impeachment 1991: Fernando Collor; 2016: Dilma Rousseff }\end{array}$} \\
\hline Economy & & Growth & Debt & Debt & Growth & Growth & Crisis and austerity \\
\hline Health system organization & Public Social & Security & & Unified Health System & (SUS) & & \\
\hline National health policies & $\begin{array}{l}\text { Hospital-bas } \\
\text { health campa }\end{array}$ & $\begin{array}{l}\text { sed and public } \\
\text { aigns }\end{array}$ & $\begin{array}{l}\text { Sanitary } \\
\text { reform }\end{array}$ & SUS implementation & $\begin{array}{l}\text { Family Health Strategy } \\
\text { networks (emergency, }\end{array}$ & $\begin{array}{l}\text { health } \\
\text { ntal health, etc.) }\end{array}$ & shrinkage of the SUS \\
\hline \multicolumn{8}{|l|}{ Local population } \\
\hline Curitiba & 180575 & 624362 & 1052147 & 1313094 & 1586848 & 1751907 & 1893997 \\
\hline Metropolitan area & & & 1563880 & 2094260 & 2813237 & 3223836 & 3537894 \\
\hline \multicolumn{8}{|l|}{ Local health services } \\
\hline Health care model & $\begin{array}{l}\text { Hospital- } \\
\text { based + } \\
\text { public } \\
\text { health } \\
\text { campaigns }\end{array}$ & $\begin{array}{l}\text { First PHC } \\
\text { units (vertical } \\
\text { programs) }\end{array}$ & $\begin{array}{l}\text { Creation of } \\
\text { Municipal } \\
\text { Health } \\
\text { Secretariat } \\
(1986)\end{array}$ & $\begin{array}{l}\text { Municipalizing of } \\
\text { health services }\end{array}$ & $\begin{array}{l}\text { Health Networks } \\
\text { ("Curitibana Mother") }\end{array}$ & $\begin{array}{l}\text { Stagnation of } \\
\text { PHC growth }\end{array}$ & $\begin{array}{l}\text { New trend of reduction of } \\
\mathrm{PHC}\end{array}$ \\
\hline Hospital beds (per 1 000) & & & & 7.46 & 6.83 & 5.93 & \\
\hline Primary care units & & & 10 & 53 & 104 & 109 & 110 \\
\hline Urgent care units (UPA) & & & & & 1 & 8 & 9 \\
\hline Psychosocial care (CAPS) & & & & & 1 & 12 & 12 \\
\hline Private plans coverage & & & & & $38.2 \%$ & $52.0 \%$ & $52.3 \%$ \\
\hline \multicolumn{8}{|l|}{ Local health indicators } \\
\hline Pregnancies with $7+$ prenatal visits & & & & $62.6 \%(1995)$ & $75.1 \%$ & $89.8 \%$ & $89.6 \%$ \\
\hline Vaccine coverage (polio) & & & & $94.3 \%$ & $96.5 \%$ & $98.2 \%$ & $91.4 \%$ \\
\hline Childbirth by cesarean & & & & $48.3 \%(1994)$ & $48.4 \%$ & $59.1 \%$ & $58.8 \%$ \\
\hline
\end{tabular}

Source: Prepared by the authors from study data.

\section{Long waiting time to secondary care}

The SUS in Curitiba has municipal services for medical and non-medical specialties, and contracts private services for outpatient and diagnostic support. Long waiting lists for consultations with specialists (average was $<3$ months, but up to 2 years) was one of the main complaints of the population. Low level of interaction among PHC and secondary care persisted despite some established mechanisms for communication, i.e., a partially-integrated electronic medical records. Most of the specialists' availability was for continuing care, which should be done by the PHC, and only about $10 \%-20 \%$ were open for new cases. As a result, specialized care was overbooked with patients whose conditions could have been treated by PHC services.

\section{Overwhelmed emergency services}

Emergency and urgent care were historically performed by hospitals in Curitiba.
In the 2000s, urgent units were created apart from hospitals. In 2013, there were eight urgent care units, the UPAs, offering 24-hr service. However, these services absorbed the failures of the health system, such as the low performance of PHC and lack of hospital beds. As a consequence, the UPAs became points of extreme tension, overwhelmed by simple cases that should be seen by PHC and by severe cases that should be admitted to the hospital.

\section{Underuse of information for health evaluation}

Even though the health surveillance sector (consisting in epidemiologic, sanitary, and environmental surveillance) was municipalized during the SUS implementation, it lacked integration with the health care units. As a consequence, in spite of having expansive databases and generating a broad range of data, health surveillance was seldomly used for performance evaluation or for improving health care delivery.

\section{Fiscal debt and administrative rigidness}

The growth of SUS services in Curitiba happened without the corresponding funding from the federal and state governments, requiring increased resources from the municipal treasury. From the early 1990s - 2013, the percentage of municipal revenue for health grew from $7 \%$ to around $18 \%$. In 2016, the total budget for health was R\$ 1.62 billion ( $\mathrm{R} \$ 858.26$ per-capita; US\$ 268.20), 52\% funded by the municipality. Despite the increase in municipal investment, the budget did not cover the total health cost. As a consequence, a fiscal debt of approximately $10 \%$ of the annual budget was incurred.

In addition, national and municipal regulations governing human resources created challenges regarding the specifics of diverse professional categories (> 7500 health professionals hired by the municipality) and services of varying levels of complexity. A public municipal foundation to manage specialized services was created in 2012, but administrative issues for human resources persisted. 
FIGURE 1. Infant mortality rate (< 1 year of age) in the city of Curitiba, Paraná, Brazil, 1994 - 2016

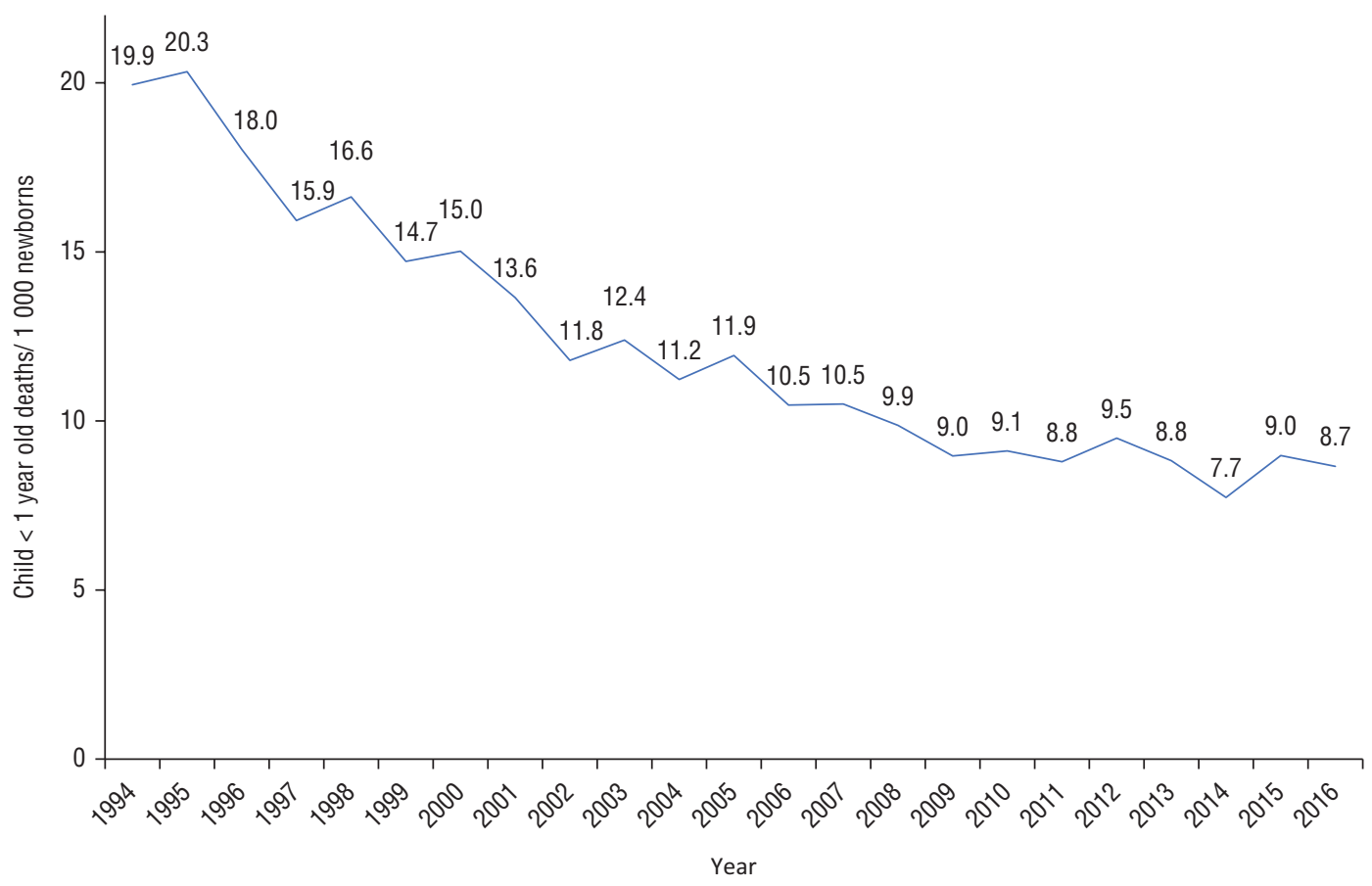

Source: Prepared by the authors with data from the Ministry of Health of Brazil, SIM Mortality Information System / SINASC - Information System on Live Births.

\section{INNOVATIONS AT THE MUNICIPAL LEVEL}

The key point for the municipal planning of 2014 - 2017 (14) was the redefinition of roles, functions, and organization to enhance the role of PHC in the health system. To develop a more accessible, comprehensive, and efficient PHC, the central idea was inducing the transformation of vertical-based health practices to a horizontal and integrated model of organization based on interaction among health networks in each health district (25). Theoretical and methodological concepts used as references were Starfield's systematization of PHC (26), Campos' "amplified clinic" and participative management (27), and the guidelines of the National Basic Care Policy (7). Several strategies were implemented:

\section{Definition of a new normative framework}

A normative framework for the role of PHC in the health system was established by a Municipal Decree in 2013 (28). It redefined guidelines and set common goals for all PHC services in Curitiba to:

- Be the main gateway to the SUS of Curitiba;
- Provide person-centered care, oriented toward families and communities;

- Stimulate civil and community participation in health care;

- Increase comprehensive care at the PHC units, at home, and in other places, throughout all phases of the lifecycle;

- Minimize the possibility of unexpected harm done to the individual and/or the population by a health intervention;

- Develop health surveillance activities throughout the area under the auspices of the PHC team;

- Develop relationships of attachment and continuity of care between health professionals and the public;

- Coordinate patient care when it involves secondary or tertiary health services.

\section{Improving access}

To facilitate the role of PHC as the main gateway to the health system, a set of measures were implemented:

a. Reclaiming the role of PHC in acute situations. The role of PHC units in acute care had been mostly dismissed since the creation of urgent care centers. It was essential that PHC resume its role of assisting in all health requests, including acute situations, for everyone in its territory. A practical guide was established to guide PHC managers and professional teams in implementing strategies to address acute and chronic needs, offering same-day appointments as a gold standard (29).

b. Enhancing nursing clinical care. To support increased access in PHC, the role of nurses in clinical care was fostered. PHC units were rebuilt so that each nurse would have their own clinical room. In 2012 2015, appointments with nurses nearly tripled. This allowed increase of care, even for patients of well-established programs, such as "Curitibana Mother." The number of prenatal care appointments per pregnancy increased from 6.44 to 7.42 from 2012 to 2016 (18). It also enabled offering more medical appointments for acute situations (Figure 2).

c. Priority for the family health model. Some PHC units were changed from the conventional model to the Family Health model. Thus, the number of Family Health units increased from 55 of the 109 PHC units in January 2013, to 66 of 110 PHC units in 2016, expanding from 185 to 225 Family Health teams in the city. 
FIGURE 2. Number of primary health care medical and nursing appointments in Unified Health System (SUS), city of Curitiba, Paraná, Brazil, 2012 - 2016

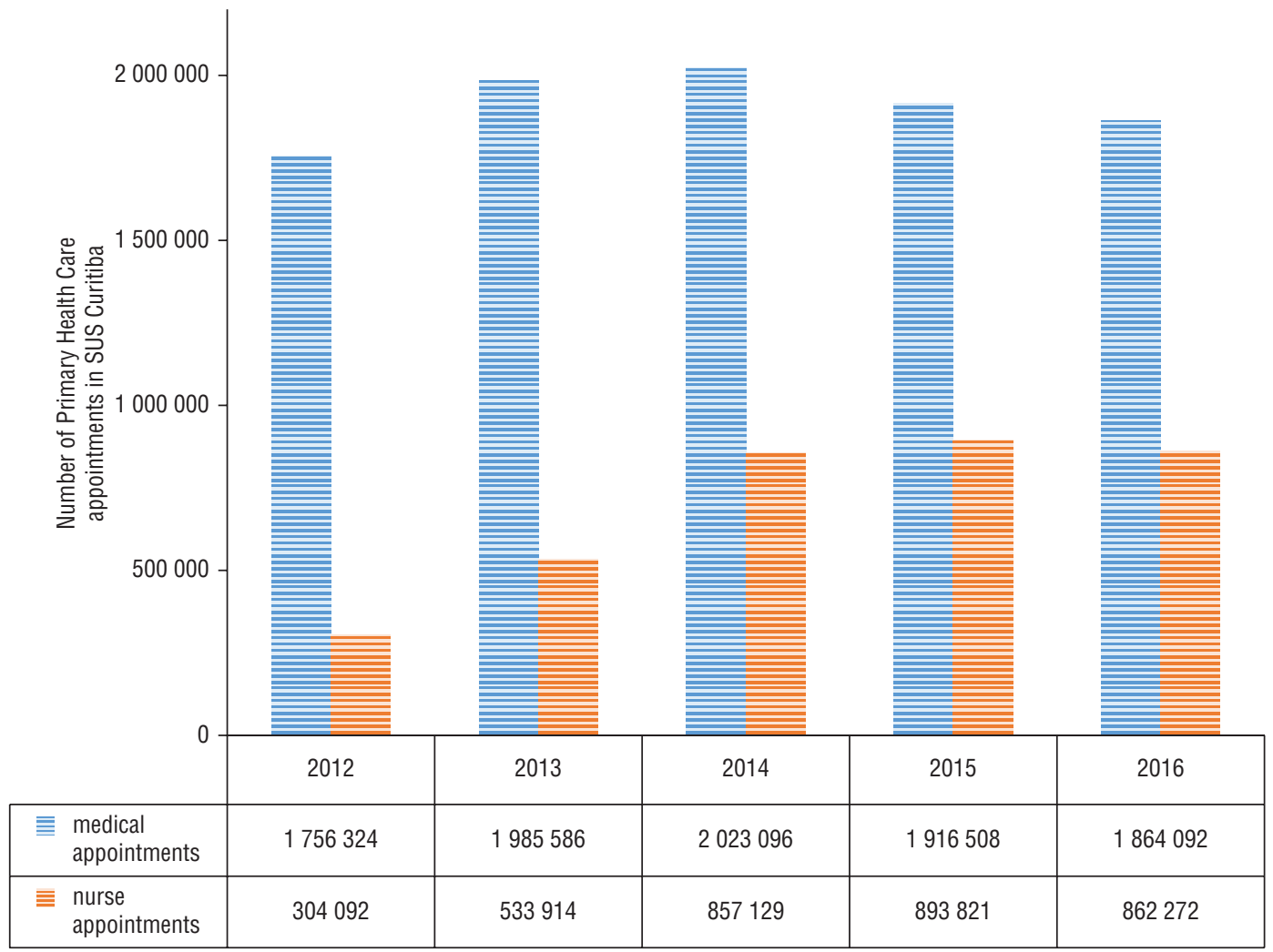

Source: Prepared by the authors with data from annual Government Reports of the Curitiba Municipal Health Secretariat (16).

d. Reorganization of appointment scheduling. Several strategies were developed to increase access to care at PHC units: avoidance of scheduling too far in advance (no more than 2 months ahead); allowing people to get appointments within 48 hours of the request; reducing the use of a pre-evaluation room (with low resolution capacity); and incentives for scheduling by telephone or e-mail (implemented by some units).

e. Extended hours at PHC units. Some PHC units (up to 11 of the 109, at least one in each health district) extended their hours of operation from 6:00 p.m. to 10:00 p.m. in order to serve the public beyond the typical working hours and to reduce the likelihood that those with urgent requests treatable by the PHC would seek care at an urgent care center.

f. Reduction of organizational barriers. Previously, a person was only granted full registration with the city health system after their address was confirmed by meeting with the
Community Health Agent for the given area. Typically, this would happen days or weeks after the initial request. Instead, this requirement was replaced by full registration upon request at the $\mathrm{PHC}$ unit with just a few simple documents.

g. Priority for vulnerable groups. Emphasis on access for vulnerable groups that did not often visit the health units. In 2013, four multi-professional teams of "Mobile Clinics" (Consultórios na Rua) were created to provide PHC for the homeless population, estimated to be about 4000 people living in several parts of $\mathrm{Cu}$ ritiba, but mostly in the central area.

\section{Service portfolio for PHC}

A portfolio of services was created, explaining the actions offered by the PHC units and detailing the expected comprehensiveness of each health team. The portfolio consists of two guides, one describes the municipal SUS to its users; the other, provides a profile of PHC services for health professionals. In addition, the portfolio has begun to serve as a basis for organizing continued education for staff and for procuring new equipment (30, 31). The purpose of the services portfolio was to:

a. Provide comprehensive performance. Some procedures that had been performed by PHC decades ago, by 2013 were rare and required reinstating: removal of cerumen from the ear, small wound sutures, minor surgeries, cauterization, biopsies, insertion of intrauterine devices, alcoholic detoxification, handling of common musculoskeletal problems, common mental health issues (e.g., anxiety), etc. These interventions started to be monitored in each PHC unit, revealing differences according to model of care (Table 2).

b. Guide technical and material support. Part of the continuing education of health professionals was directly linked to the use of new equipment, such as electrosurgery devices and spirometers 
or digital electrocardiograms, but most was directed toward broadening the clinical care capability of each professional on a multiprofessional PHC team. A fundamental step in this process was training professionals to offer new services. This was accomplished gradually in a variety of ways by each health district and PHC unit.

\section{Coordination of care}

In a complex health system with different specialized services operating under various organizational logistics (emergency, mental health, hospital, outpatient specialties, etc.), PHC must play a fundamental role in coordination. Several strategies were developed to improve this capacity (Figure 3):

a. Collaborative care. Collaborative care in the PHC multiprofessional teams was fostered, along with expanding the clinical roles of all of its professionals-even pharmacists who had rarely assisted patients directly before. Collaboration was boosted by greater proximity of physicians' and nurses' offices at the units. Common health issues that are better tackled by a collaborative effort required that each professional's role be clarified; for example, actions to be taken by nutritionists, physical educators, and physicians caring for a person with obesity, or interventions by psychologists, nurses, and physicians when assisting a person who has attempted suicide. b. Technical and pedagogical specialized support for PHC in loco. Family Health Support Groups (Núcleo de Apoio à Saúde da Família; NASF) provide specialized support for PHC. NASF is composed of multiprofessional teams: nutritionists, pharmacists, physical educators, physiotherapists, and psychologists. Other specialists, such as pediatricians, gynecologists, psychiatrists, infectiologists, and gerontologists were included according to local needs and to enhance the comprehensiveness of the NASF. Each NASF was charged with supporting PHC teams in a given geographic area. Clinical care actions (individual or in group) were encouraged, in addition to collective care/educational roles. Also, case management and review of waiting lists of patients referred for secondary care led to improved clinical competence in PHC.

c. Clinical regulation of referrals to specialties. As there were many waiting lists, those not in charge of NASF were monitored with different strategies, aiming to achieve waiting list management according to clinical priorities and vulnerability. Even though an existing computer system was being used to organize the queues, this was done passively, and there were so many cases marked "priority," that any case not marked as such would not able to get an appointment. Gradually, from 2013 onward, these virtual queues became "actively" regulated, leading to

TABLE 2. Primary health care (PHC) units performing select procedures, according to model of care (family health or conventional PHC unit), in the city of Curitiba, Paraná, Brazil, 2014

\begin{tabular}{lccc}
\hline & Total (\%) & Family health units (\%) & Conventional units (\%) \\
\hline Suture & 53.1 & 68.5 & 33.3 \\
Abscess drainage & 57.3 & 81.5 & 26.2 \\
Ingrown nail surgery & 41.2 & 61.1 & 16.7 \\
Skin biopsy & 32.3 & 44.4 & 30.9 \\
Subcutaneous procedure & 21.9 & 33.3 & 7.1 \\
Ear wax removal & 69.8 & 96.3 & 35.7 \\
Intrauterine device insertion & 73.9 & 74.1 & 73.8 \\
Wart cautherization & 61.5 & 70.4 & 50.0 \\
Bladder cateter & 98.9 & 100.0 & 97.6 \\
Nasogastric tube & 89.6 & 94.4 & 83.3 \\
Special wound dressing & 85.4 & 92.6 & 76.2 \\
Unerupted teeth & 36.4 & 35.2 & 38.1 \\
\hline
\end{tabular}

Source: Prepared by the authors with 2014 data from the City of Curitiba, Department of Primary Care, Curitiba Municipal Health Secretariat.

shorter waiting times for most. Experiences of clinical regulation were implemented through in-person or virtual evaluation. For example, in early 2013, there were 763 pregnant women who were waiting up to 4 months for specialized prenatal care due to risks identified at PHC. With rapidly-implemented, in-person evaluations of all of them, continuous monitoring of the virtual queue, and fast track strategies to prioritized cases, the waiting times were reduced to a few weeks (18).

d. Virtual regulation by tele-health. This experience started with neurology. Every referral from PHC to secondary care had to be virtually discussed with a dedicated team of family physicians who were supported by the neurologists of a tertiary-level teaching hospital, using the Tele-health (Telessaúde) national software. Cases treatable at $\mathrm{PHC}$ received adequate care and were not put on the wait list; while situations with higher complexity or red flags were addressed promptly by neurologists and/or specialized exams. A few months after implementation, in 2013, the wait for a new appointment with a neurologist dropped from almost 2 years to less than 1 month (32).

e. Improvement in referrals and counter-referrals. Regulation between PHC and specialized care also resulted in educational opportunities for health professionals and important changes in referral behavior: reduction of referrals by PHC to secondary care and an increased counter-referrals by secondary and tertiary care to PHC.

\section{LOOKING AHEAD}

Exploring the local experiences of innovative municipalities in decentralized health systems provides outstanding contributions to understanding health systems in the Latin American context. In Curitiba, the historical analysis highlights the key role of urban planning in the implementation of PHC, influenced by the Alma-Ata recommendations before there were any national policies for the area. After 40 years, the expansion of PHC changed the model of hospital-based health care. However, the sub-optimal functioning of PHC is an 
FIGURE 3. Regulation of referrals from primary health care to specialized care, mediated by family health support groups (NASF) teams or tele-health, in the SUS of the city of Curitiba, from 2014 to 2016

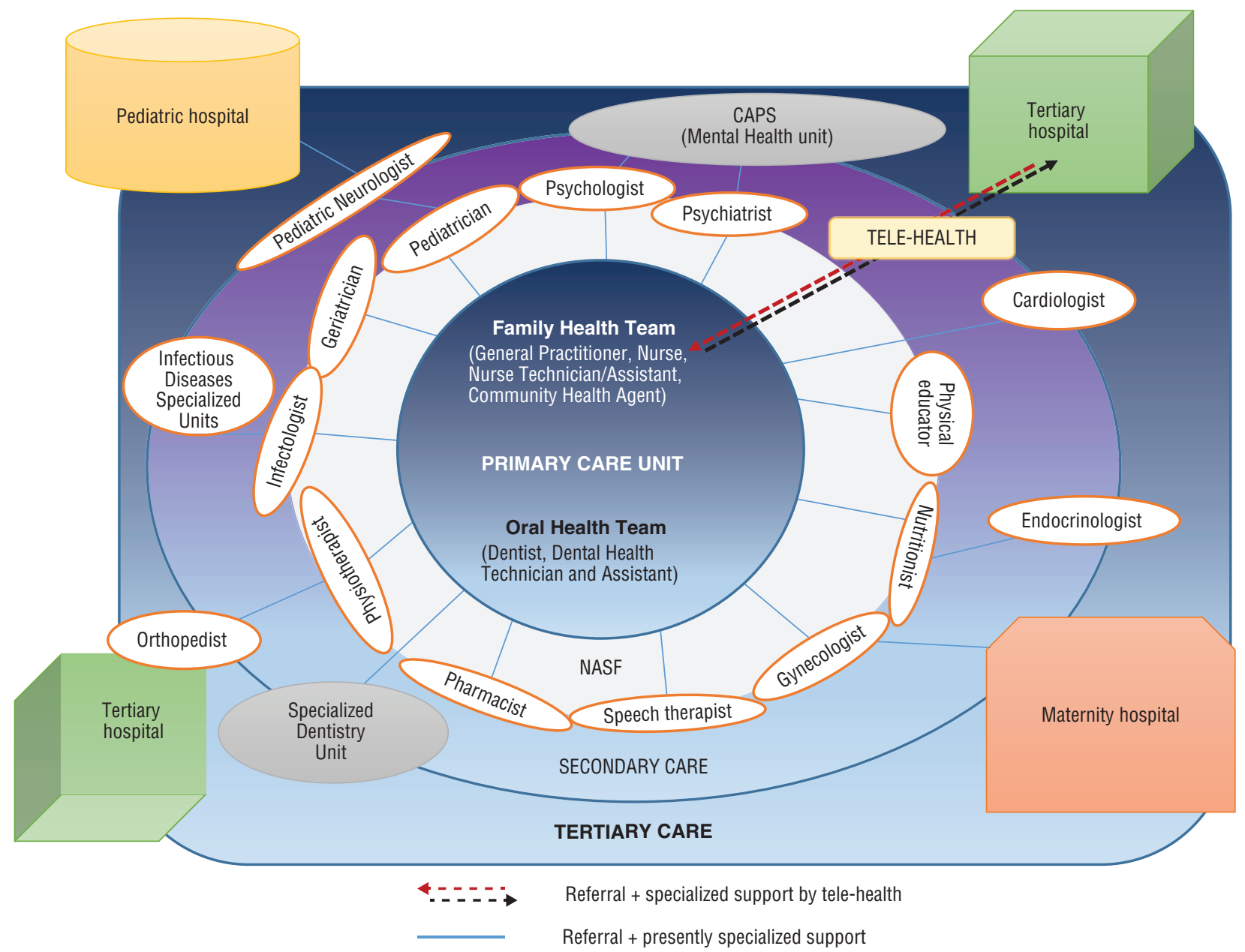

Source: Prepared by the authors from study data.

important cause of health system failures, requiring permanent capacity for innovation.

The prioritization of PHC in the health system in Curitiba, together with the introduction of the innovative practices described in this report, produced increased access, improved performance, and better coordination of care by PHC teams. The investment in improving professional clinical skills and the ability to work through multiprofessional teams in health networks that interact with the various specialized care services were some of the more successful measures taken.

However, more than organizational changes, health system innovation involves the transformation of people and cultures, demanding time and continuity to become well established.
Thus, the structural weaknesses of SUS, aggravated by austerity, threaten the achievements so recently obtained. Sadly, disruption of successful health policies and reduction of public health services are underway in Brazil $(13,33)$.

Finally, we highlight the fundamental role of international guidelines for health systems in hard times. In the midst of a military dictatorship, Alma-Ata's recommendations promoted the first experiences of PHC in Brazil. Today, in a context of austerity, the SDGs reaffirm the right to universal health care-not just basic packages for the poor-to prevent setbacks and to enable better health for all.

Acknowledgements. We would like to thank the City of Curitiba and all the SUS health professionals working in primary health care in $2013-2016$.

Conflicts of interest. Adriano Massuda was Secretary of Health in Curitiba from January 2013 - July 2015. César M. S. Titton was Secretary of Health in Curitiba from August 2015 December 2016. Paulo Poli Neto was Director of the Primary Care Department at the Secretariat of Health of Curitiba from January 2013 - April 2016. The authors declare no other conflicts of interest.

Disclaimer. Authors hold sole responsibility for the views expressed in the manuscript, which may not necessarily reflect the opinion or policy of the RPSP/ PAJPH and/or PAHO. 


\section{REFERENCES}

1. World Health Organization. Declaration of Alma-Ata International Conference on Primary Health Care, Alma-Ata, USSR, 6-12 September 1978. Available from: www.who.int/publications / almaata declaration_en.pdf Accessed 20 January 2018.

2. Brazil. Constituição da República Federativa do Brasil. Brasília, DF. Available from: www.planalto.gov.br/ ccivil_03/constituicao/constituicaocompilado.htm Accessed 20 January 2018.

3. Pan American Health Organization. Resolution CD53.R14: Strategy for universal access to health and universal health coverage. Proceedings of the 53rd Directing Council, 66th Session of the Regional Committee of WHO for the Americas. Washington, DC: PAHO; 2014.

4. Atun R, De Andrade LO, Almeida G, Cotlear D, Dmytraczenko T, Frenz P, et al. Health-system reform and universal health coverage in Latin America. Lancet. 2015;385(9974):1230-47.

5. Paim J, Travassos C, Almeida C, Bahia L, Macinko J. The Brazilian health system: history, advances, and challenges. Lancet. 2011;377(9779):1778-97.

6. Viana AL, da Silva HP, Yi I. Universalizing health care in Brazil: Opportunities and challenges. Geneva: UNRISD; 2015.

7. Brazil, Ministry of Health. Aprova a política nacional de atenção básica, estabelecendo a revisão de diretrizes e normas para a organização da Atenção Básica para o Programa Saúde da Família (PSF) e o Programa Agentes Comunitários de Saúde (PACS). Available from: http://bvsms. saude.gov.br/bvs/saudelegis/gm/2006/ prt0648_28_03_2006.html Accessed 20 January 2018

8. Barreto ML, Rasella D, Machado DB, Aquino R, Lima D, Garcia LP, et al. Monitoring and evaluating progress towards universal health coverage in Brazil. PLoS Med. 2014;11(9):e1001692.

9. Macinko J, Dourado I, Aquino R, Bonolo PD, Lima-Costa MF, Medina MG, et al. Major expansion of primary care in Brazil linked to decline in unnecessary hospitalization. Health Affairs. 2010;29(12):2149-60.

10. Hone T, Rasella D, Barreto M, Atun R, Majeed A, Millett C. Large reductions in amenable mortality associated with Brazil's primary care expansion and strong health governance. Health Affairs. 2017; 36(1):149-58.

11. Hone T, Rasella D, Barreto ML, Majeed A, Millett C. Association between expansion of primary healthcare and racial inequalities in mortality amenable to primary care in Brazil: a national longitudinal analysis. PLoS Med. 2017;14(5):e1002306.

12. Fausto MC, Bousquat A, Lima JG, Giovanella L, de Almeida PF, de Mendonça $\mathrm{MH}$, et al. Evaluation of Brazilian primary health care from the perspective of the users: accessible, continuous, and acceptable? J Ambul Care Manage. 2017; 40(2 Suppl):S60.

13. Massuda A, Hone T, Leles FA, de Castro MC, Atun R. The Brazilian health system at crossroads: progress, crisis and resilience. BMJ Glob Health. 2018;3(4):e000829.

14. Watts J. Brazil's health system woes worsen in economic crisis. Lancet. 2016;16;387(10028):1603-4.

15. United Nations Development Program, the Institute for Applied Economic Research, João Pinheiro Foundation. Atlas of human development in Brazil. 2013. Available from: www.atlasbrasil.org.br/2013/en/perfil m/curitiba_pr/Accessed 20 January 2018.

16. Mills A. Health care systems in low-and middle-income countries. New Engl J Med. 2014;370(6):552-7.

17. Curitiba Municipal Health Secretariat. Municipal health plan 2014 - 2017 Available from: www.saude.curitiba.pr. gov.br/images/Plano_curvas.pdf Accessed 20 January 2018.

18. Curitiba Municipal Health Secretariat. Government reports 2013 - 2016. Available from: www.saude.curitiba.pr.gov.br/asecretaria/ relatorios-de-gestao.html Accessed 20 January 2018.

19. Curitiba Municipal Health Secretariat. Epidemiologic Bulletin. January 2014. Available from: www.saude.curitiba. pr.gov.br/images / Boletim Epide miológico\%202013.2.pdf Accessed 20 Jan 2018

20. Massuda A. Construindo novos caminhos para a reforma na saúde: reflexões sobre a práxis da formulação e implementação de mudanças na gestão e no modo de produção de práticas de saúde no SUS em Curitiba [tese]. Campinas: Universidade Estadual de Campinas; 2014

21. Moyses SJ, Oliveira CA, D'angelis MA, Paciornik EF. A construção social do distrito sanitario. In: Ducci L, Pedotti MA, Simão MG, Moyses SJ, eds. Curitiba: a saude de bracos abertos. Rio de Janeiro: Cebes; 2001.

22. Jimenez EJB, Simao MBG, Shimazaki ME. Programa Mãe Curitibana: avançando na humanização da atenção maternoinfantil. Divulg Saúde Debate. 2004;30: 21-29.

23. Afonso MP, Shimizu HE, MerchanHamann E, Ramalho WM, Afonso T. Association between hospitalisation for ambulatory care-sensitive conditions and primary health care physician specialisation: a cross-sectional ecological study in Curitiba (Brazil). BMJ Open. 2017;1;7 (12):e015322.

24. Brazilian Forum of Public Security. Statistical yearbook of public security. 2017. Available from: www.forumseguranca.org.br/ativities/anuario Accessed 27 July 2018.

25. Massuda A, Poli Neto P, Drehmer V. A atenção primária à saúde (APS) no SUS
Curitiba: um desafio para o Brasil, passar de uma APS programática para uma mais acessível e abrangente. In: Souza MF, Machado MS, Mendonça AVM, eds. Saúde da Família nos Municípios Brasileiros: os reflexos dos 20 anos no espelho do futuro. Campinas: Saberes; 2014. Pp. $121-77$.

26. Starfield B. Atenção primária: equilíbrio entre necessidades de saúde, serviços e tecnologia. Brasília: UNESCO, Ministério da Saúde; 2002. Available from: http://bvsms. saude.gov.br/bvs/publicacoes/atencao_ primaria_p1.pdf Accessed 16 August 2018.

27. Campos GWS, Guerreiro AVP. Manual de práticas de atenção básica: saúde ampliada compartilhada. São Paulo: Hucitec; 2010.

28. Municipality of Curitiba. Decree 560: dispõe sobre regulamentação da atenção primária à saúde na Secretaria Municipal da Saúde. Available from: http://mediaenterprise.dohmsweb.com.br/mediafiles. sismuc.org.br/legislacao/264_1271.pdf Accessed 16 August 2018.

29. Curitiba Municipal Health Secretariat. Novas possibilidades de organizar o acesso e a agenda na Atenção Primária à Saúde. Available from: http://arquivos. leonardof.med.br/Saude Curitiba CartilhaAcessoAvancado_2014-06-05.pdf Accessed 20 July 2018

30. Curitiba Municipal Health Secretariat. Carteira de serviços: guia para profissionais de saúde. Relação de serviços e condições abordadas na APS. Available from: www.saude.curitiba.pr.gov.br/images/ Manual\%2014abr14.pdf Accessed 20 July 2018.

31. Curitiba Municipal Health Secretariat. Carteira de serviços do SUS em Curitiba. Available from: www.saude.curitiba.pr. gov.br/images/Apostila\%20Sus_14jan14 VISUALIZACAO.pdf Accessed 20 July 2018.

32. Poli Neto P, Bagatelli RC, Silveira ME, Ribas LFO, Mulinari RA. Telessaúde na regulação da neurologia em Curitiba. In: Moysés SJ, Silveira Filho AD, eds. A gestão participativa na saúde de Curitiba. Curitiba: Instituto Municipal de Administração Pública; 2016. Pp. 49 - 60.

33. Rasella D, Basu S, Hone T, Paes-Sousa R, Ocké-Reis CO, Millett C. Child morbidity and mortality associated with alternative policy responses to the economic crisis in Brazil: a nationwide microsimulation study. PLoS Med. 2018;15(5):e1002570.

Manuscript received on 14 January 2018. Accepted for publication on 10 August 2018 
RESUMEN

Recordando a Alma-Ata: desafíos e innovaciones en la atención primaria de salud en una ciudad de ingresos medios en América Latina

Palabras clave
El año 2018 es un momento oportuno para explorar las reformas del sistema de salud y la atención primaria de salud (APS) en Brasil, dados los aniversarios de la Declaración de Alma-Ata (40 años) y de la Constitución de Brasil (30 años), las bases del Sistema Único de Salud (SUS). En este contexto, el análisis del sistema de salud en el ámbito municipal es un instrumento importante para reconocer los logros e innovaciones, así como las debilidades y amenazas. Debido al principio de descentralización del SUS, los municipios han asumido un papel de liderazgo en el desarrollo y la implementación de políticas de salud. Las ciudades también son las primeras en expresar las deficiencias del sistema de salud y las consecuencias de las medidas de austeridad. Por lo tanto, el análisis de las transformaciones del sistema de salud a nivel municipal es fundamental para estudiar los logros y las brechas de la APS.

Este informe identifica los desafíos y las innovaciones de la implementación de la APS en Curitiba, comenzando con una breve historia del desarrollo del sistema de salud de la ciudad. La ciudad fue pionera en vincular la planificación urbana con el diseño del sistema de salud, mejorar el acceso a la atención sanitaria y obtener mejores resultados de salud en los últimos 30 años. Este informe se enfoca en ese periodo, así como los desafíos y las estrategias implementados durante el ciclo político más reciente (2013-2016). Hay lecciones sustanciales que se pueden obtener de la experiencia de esta ciudad de ingresos medios en América Latina, que pueden ser útiles a medida que la región avanza hacia el Objetivo de Desarrollo Sostenible de la cobertura universal de salud para el año 2030.

Atención primaria de salud; reforma de la atención de salud; actos internacionales; cobertura universal de salud; Brasil; América Latina.
RESUMO

Relembrando Alma-Ata:
desafios e inovações na
atenção primária à saúde
em uma cidade de renda
média na América Latina

Relembrando Alma-Ata: desafios e inovações na em uma cidade de renda média na América Latina
O ano de 2018 é um momento oportuno para explorar as reformas do sistema de saúde e atenção primária à saúde (APS) no Brasil, considerando os aniversários da Declaração de Alma-Ata (40 anos) e da Constituição do Brasil (30 anos), as bases do Sistema Único de Saúde (SUS). Neste contexto, a análise do sistema de saúde no cenário municipal é um instrumento importante para reconhecer realizações e inovações, bem como fraquezas e ameaças. Devido ao princípio de descentralização do SUS, os municípios assumiram um papel de liderança no desenvolvimento e implementação de políticas de saúde. As cidades também são as primeiras a expressar os fracassos do sistema de saúde e as conseqüências das medidas de austeridade. Assim, a análise das transformações do sistema de saúde no nível municipal é fundamental para o estudo das conquistas e lacunas da APS.

Este relatório identifica os desafios e inovações da implementação da APS em Curitiba, começando com uma breve história do desenvolvimento do sistema de saúde da cidade. A cidade foi pioneira em vincular o planejamento urbano com desenho dos sistemas de saúde, melhorando o acesso aos serviços de saúde e obtendo melhores resultados de saúde nos últimos 30 anos. Este relatório abrange esses anos, assim como os desafios e estratégias implementados durante o ciclo político mais recente (2013-2016). Há lições substanciais que podem ser extraídas da experiência desta cidade de renda média na América Latina, lições que podem ser úteis à medida que a região avança em direção ao Objetivo de Desenvolvimento Sustentável da cobertura universal de Saúde até 2030.

Palavras-chave
Atenção primária à saúde; reforma dos serviços de saúde; atos internacionais; cobertura universal de saúde; Brasil; América Latina. 